\title{
ARTIKELEN
}

\section{Navigeren door het labyrint van grensoverschrijdende detachering}

\section{De fundamentele verkeersvrijheden, de Detacheringsrichtlijn en het internationaal privaatrecht}

\author{
Femke Laagland
}

\section{Aanleiding en probleemstelling}

De detachering van buitenlandse werknemers naar Nederland is populair. Sinds het openstellen van de grenzen met onder meer Polen, Bulgarije en Hongarije wordt steeds meer van deze vorm van arbeid gebruikgemaakt. ${ }^{1}$ Het vrije dienstenverkeer lijkt een succesverhaal. Maar is dat ook zo? De laatste tijd zijn kritische geluiden hoorbaar. In een reactie op het SER-advies Arbeidsmigratie uit 2015 noemt het kabinet maatschappelijke fricties en oneerlijke concurrentie als schaduwkanten van de grensoverschrijdende arbeidsmobiliteit. ${ }^{2}$ Minister Asscher pleit zelfs voor gelijk loon voor gelijke arbeid op dezelfde werkplek in de gehele Europese Unie. ${ }^{3}$ Een oproep waaraan de Europese Commissie gehoor geeft in haar voorstel tot aanpassing van de Detacheringsrichtlijn van maart dit jaar. ${ }^{4}$ De politieke initiatieven stemmen overeen met de maatschappelijke commotie. Koppen zoals 'Slaven van de A2' en 'Uitbuiting bij transport personenauto's Mercedes' doen vermoeden dat het openstellen van de grenzen tot de uitbuiting van buitenlandse werknemers heeft geleid.

De vraag hoeveel werknemersbescherming lidstaten aan uit het buitenland gedetacheerde werknemers kunnen toekennen, heeft de gemoederen lange tijd beziggehouden. Het Hof van Justitie oordeelde in de zaak Laval dat de mate van bescherming is beperkt tot de hardekern-arbeidsvoorwaarden uit de Detacheringsrichtlijn. ${ }^{5}$ De uitspraak bracht duidelijkheid, maar heeft ook tot nieuwe uitdagingen geleid. Verschillende constructies zijn ingezet om de loonkosten zo laag mogelijk te houden. Denk aan het vermijden van permanente detachering, maar ook aan het oprichten van buitenlandse bv's die werknemers naar Nederlandse

1 Commission Staf Working Document Impact Assessment, SWD(2016)52 final, p. 6-8.

2 Kabinetsreactie SER-advies Arbeidsmigratie d.d. 16 juni 2015, p. 2.

3 Minister Asscher, Brief aan Eurocommissaris Thyssen over de Detacheringsrichtlijn, 18 juni 2015. De brief is mede ondertekend door Frankrijk, Duitsland, Zweden, België, Luxemburg en Oostenrijk.

4 Proposal for a Directive of the European Parliament and of the Council amending Directive 69/71/EC of the European Parliament and of the Council of 16 December 1996 concerning the posting of workers in the framework of the provision of services, $\operatorname{COM}(2016) 128$ final.

5 HvJ EG 19 juni 2007, C-341/05, JAR 2008/21 (Laval). 
concernonderdelen detacheren. De constructies zijn lucratief omdat de juridische status van de buitenlandse werknemer bepaalt waarop hij recht heeft. De verschillen zijn groot. De buitenlandse werknemer heeft de ene keer recht op enkel de hardekern-arbeidsvoorwaarden en de andere keer op alle (dwingende) arbeidsrechtelijke bepalingen uit het werkland. Bovendien kennen de verschillende typen detachering uit de Detacheringsrichtlijn - contracting, intra-concernuitlening en uitzending - ook elk hun eigen arbeidsrechtelijke regime. Wanneer nu welk arbeidsrechtelijk regime geldt en waarom is echter niet steeds eenvoudig te achterhalen.

Door de jaren heen is een wirwar aan Europese en nationale regels ontstaan. Wie zich met grensoverschrijdende detachering bezighoudt, krijgt te maken met de fundamentele verkeersvrijheden, het internationaal privaatrecht en het nationale materiële arbeidsrecht. Hoe verhouden deze regels zich tot elkaar en wat zijn de consequenties voor de verschillende detacheringsvormen? Deze vragen staan in dit artikel centraal. Bij de beantwoording wordt ook een blik vooruit geworpen naar de wijzigingen die het voorstel tot aanpassing van de Detacheringsrichtlijn voorstelt. Ondanks het verzet van verschillende (vooral Oost-Europese) lidstaten, maakte de Europese Commissie eind juli bekend het voorstel aan te houden. ${ }^{6}$ De auteur gaat na of het voorstel leidt tot een eenduidiger systeem zodat meer rechtszekerheid ontstaat en regime-shopping minder aantrekkelijk wordt.

De opbouw van het artikel is als volgt. Eerst is aandacht voor de positie van de Detacheringsrichtlijn binnen het internationaal privaatrecht (paragraaf 2), de betekenis van het begrip tijdelijkheid (paragraaf 3) en de juridische consequenties indien het niet om tijdelijke maar om permanente detachering gaat (paragraaf 4). Deze paragrafen schetsen het Europese kader. Bedacht moet worden dat de Detacheringsrichtlijn slechts de verschillende normen coördineert die op nationaal niveau bestaan. Het Nederlandse recht speelt een belangrijke rol bij het vaststellen op welke arbeidsvoorwaarden recht bestaat. De juridische dynamiek tussen het Europese en het Nederlandse recht vormt dan ook de context waarbinnen de verschillende detacheringsconstructies worden geanalyseerd (paragraaf 5). Het artikel is geschreven vanuit het perspectief dat een buitenlandse werknemer vanuit een lidstaat met een laag loonkostenniveau naar Nederland als lidstaat met een hoog loonkostenniveau wordt gedetacheerd. Handhavingsperikelen komen alleen aan bod voor zover relevant voor de vraagstelling.

\section{Het toepasselijke recht bij tijdelijke detachering}

\subsection{Het internationaal privaatrecht in het licht van de verkeersvrijheden}

De vrijheid van diensten is verankerd in artikel 56 van het Verdrag betreffende de werking van de Europese Unie (VWEU). Het artikel biedt ondernemers de moge-

6 Elf lidstaten trokken een gele kaart omdat naar hun mening het voorstel niet zou voldoen aan het subsidiairiteitsbeginsel. De Europese Commissie legde de gele kaarten naast zich neer. Volgens de Europese Commissie heeft Europa wel de bevoegdheid over dit onderwerp wetgeving te maken. Persbericht - Europese Commissie d.d. 20 juli 2016, IP 16/2546. 
lijkheid hun diensten aan te bieden in een andere lidstaat dan de lidstaat van vestiging. Dat kan via het verrichten van een dienst waarvoor de dienstverrichter zijn eigen werknemers inzet, maar de dienst op zichzelf kan ook zien op het ter beschikking stellen van werknemers (in of buiten concernverband). De werknemers blijven bij een tijdelijke detachering naar het buitenland onderworpen aan de arbeidswetgeving van het land waar zij gewoonlijk werkzaam zijn. Dat zit als volgt. Het toepasselijke recht wordt bepaald op basis van Verordening 593/2008 (hierna: Rome I-Verordening). ${ }^{7}$ De Rome I-Verordening kent met artikel 8 speciale verwijzingsregels voor de arbeidsovereenkomst. Artikel 8 lid 2 regelt dat partijen niet kunnen afwijken van de dwingende bepalingen van het recht van het land waar de werknemer ter uitvoering van de overeenkomst gewoonlijk zijn werkzaamheden verricht. ${ }^{8}$ Hier zit de crux. In het gewoonlijke werkland treedt geen wijziging op wanneer de werknemer slechts tijdelijk in een ander land is tewerkgesteld. ${ }^{9}$

De uitkomst van de Rome I-Verordening leidt tot een spanningsveld in de relatie tussen lage- en hogelonenlanden. Artikel 8 lid 2 Rome I-Verordening heeft tot gevolg dat dienstverrichters uit lagelonenlanden (zoals Polen en Bulgarije) hun diensten in hogelonenlanden (zoals Nederland) kunnen aanbieden tegen een lager tarief omdat zij hun werknemers minder betalen dan in het tijdelijke werkland gebruikelijk is. Dit leidt tot oneerlijke concurrentie tussen dienstverrichters. Bovendien ontvangen buitenlandse werknemers in de hiervoor geschetste situatie een loon dat in het tijdelijke werkland als sociaal onaanvaardbaar wordt beschouwd, gezien het daar geldende welvaartsniveau. De Detacheringsrichtlijn bepaalt in het licht van de vrijheid van diensten welke maatregelen lidstaten mogen nemen ter bescherming van de eigen arbeidsmarkt. Bij een tijdelijke detachering heeft de werknemer alsnog recht op de harde kern van arbeidsvoorwaarden zoals die gelden in het tijdelijke werkland. Tot de harde kern behoren onder meer regels inzake het minimumloon, het minimale aantal doorbetaalde vakantiedagen, en gezondheid, veiligheid en hygiëne op het werk (zie artikel 3 lid 1 Detacheringsrichtlijn).

De vraag naar het toepasselijke recht bij tijdelijke detachering staat in het teken van de vrijheid van diensten. Dat bevreemdt. De reden dat artikel 8 Rome I-Verordening bepaalt dat bij een tijdelijke tewerkstelling in een andere lidstaat geen wijziging optreedt in het toepasselijke recht, is de bescherming van de werkne-

7 Verordening (EG) 593/2008 van het Europees Parlement en de Raad van 17 juni 2008 inzake het recht dat van toepassing is op verbintenissen uit overeenkomst (PbEG 2008, L 177/1).

8 De rechtskeuze kan er niet toe leiden dat de werknemer de bescherming verliest die hij geniet op grond van de dwingende bepalingen uit het objectief toepasselijke recht. De rechtskeuze is slechts relevant voor de bepalingen van regelend recht. Ontbreekt een rechtskeuze, dan geldt het objectief toepasselijke recht waarnaar artikel 8 Rome I-Verordening verwijst voor zowel het regelende als het dwingende recht.

9 Zie overweging 36 preambule Rome I-Verordening. 
mer. ${ }^{10}$ De gedachte is dat de werknemer geen onderdeel wordt van de sociaaleconomische verhoudingen van een land waar hij slechts tijdelijk arbeid verricht in dienst van een buitenlandse dienstverrichter. ${ }^{11}$ De werknemer is het meest gebaat bij de toepassing van de dwingende bepalingen uit het recht van het land waar hij doorgaans werkt. Artikel 8 Rome I-Verordening is niet gebaseerd op de vrijheid van diensten. Toch werkt de bepaling tegenwoordig in het voordeel van de dienstverrichter uit. Het is immers vooral de dienstverrichter uit een lagelonenland die ervan profiteert dat op de arbeidsovereenkomst het recht van het gewoonlijke werkland van toepassing blijft. De Detacheringsrichtlijn brengt op deze uitkomst een correctie aan, maar doet dat met verwijzing naar de vrijheid van diensten slechts tot het niveau van de harde kern van arbeidsvoorwaarden uit het tijdelijke werkland.

Bovendien ontbreekt elke aandacht voor de vrijheid van werknemers. In het arrest Vicoplus uit 2011 overwoog het Hof van Justitie dat een onderneming die arbeidskrachten in het buitenland ter beschikking stelt, dienstverrichter is, maar tevens werkzaamheden verricht die tot doel hebben werknemers toegang te geven tot de arbeidsmarkt van de ontvangstlidstaat. ${ }^{12}$ Bij grensoverschrijdende uitzending geldt daarom - naast de vrijheid van diensten - de vrijheid van werknemers. Dit zal bij intra-concernuitlening niet anders zijn. ${ }^{13}$ De vrijheid van werknemers biedt buitenlandse werknemers recht op dezelfde arbeidsvoorwaarden als die gelden voor onderdanen van het werkland (en dus niet alleen de hardekernarbeidsvoorwaarden). Dit verbod op discriminatie is uitdrukkelijk opgenomen in artikel 7 Verordening (EU) 492/2011. ${ }^{14}$ De korte duur van het werk en het afwezig zijn van de bedoeling echt te integreren op de arbeidsmarkt van het werkland

10 Uit het bij het EVO-Verdrag toelichtende rapport van Giuliano en Lagarde blijkt dat artikel 6 is ontworpen om te voldoen aan 'de behoefte aan een regeling die toegespitst is op de onder onderhavige onderwerpen, waarbij de ene partij overwicht heeft op de andere zodat de partij die in sociaaleconomisch opzicht in de contractuele relatie de wakkere is tegelijkertijd beter wordt beschermd'. Toelichtend rapport, PbEG C 282, 31 oktober 1980. Artikel 8 Rome I-Verordening vertoont grote gelijkenis met artikel 8 EVO-Verdrag en is op dezelfde ratio gestoeld.

11 Met de vaststelling van het gewoonlijke werkland staat nog niet met zekerheid vast dat het recht van dat land ook het objectief toepasselijke recht betreft. Op grond van artikel 8 lid 4 Rome IVerordening kan het recht van het gewoonlijke werkland buiten toepassing blijven indien uit het geheel der omstandigheden blijkt dat de arbeidsovereenkomst een kennelijke nauwere band heeft met een ander land. Zie nader paragraaf 3.

12 HvJ EG 27 maart 1990, C-113/89 (Rush Portuguesa); HvJ EU 10 februari 2011, C-307/09-309/09 (Vicoplus).

13 In HvJ EU 10 februari 2011, C-307/09-309/09, punt 50 (Vicoplus) merkt het Hof van Justitie op dat de hoofdactiviteit van de werkgever en de door de gedetacheerde werknemer in de ontvangstlidstaat verrichte taken niet altijd overeen hoeven te komen om toch te voldoen aan de onderscheiden kenmerken van uitzending. Een omstandigheid die volgens het Hof van Justitie vooral speelt bij intra-concernuitlening. Deze overweging lijkt erop te duiden dat ook intra-concernuitlening in beginsel het verplaatsen van werknemers als doel heeft, zodat ook dan zowel de vrijheid van diensten als de vrijheid van werknemers van toepassing is.

14 Verordening (EU) 492/2011 van het Europees Parlement en de Raad van 5 april 2011 betreffende het vrije verkeer van werknemers binnen de Unie. Tevens vermeldt overweging 5 van de preambule dat de Verordening ook van toepassing is op werknemers die arbeid verrichten in het kader van een dienstverlening. 
zijn volgens het Hof van Justitie geen argumenten om de vrijheid van werknemers opzij te zetten. ${ }^{15}$

Toch heeft de buitenlandse uitzendkracht geen recht op alle dwingende arbeidsrechtelijke bepalingen die gelden in het tijdelijke werkland, maar bestaat slechts recht op de harde kern. Het enige verschil met de hiervoor genoemde arresten van het Hof van Justitie is dat bij uitzending de tijdelijkheid van het werk (ook) plaatsvindt op basis van de vrijheid van diensten. Dat is kennelijk voldoende om de vraag naar het toepasselijke recht bij tijdelijke uitzending geheel te plaatsen in het licht van de vrijheid van diensten. Via de Rome I-Verordening blijkt het verbod van discriminatie op grond van nationaliteit aldus eenvoudig te kunnen worden omzeild.

\subsection{De Detacheringsrichtlijn: voorrangsregel of zelfstandige verwijzingssystematiek?}

In het algemeen wordt (vrij eenvoudig) aangenomen dat de Detacheringsrichtlijn heeft te gelden als voorrangsregel in de zin van artikel 9 Rome I-Verordening en via die route het op de arbeidsovereenkomst toepasselijke recht doorbreekt. ${ }^{16}$ Hoewel nergens expliciet is benoemd dat de Detacheringsrichtlijn een voorrangsregel is, biedt overweging 34 van de preambule bij de Rome I-Verordening een argument voor deze zienswijze. Deze overweging bepaalt dat artikel 8 Rome IVerordening geen afbreuk doet aan de toepassing van de bepalingen van bijzonder dwingend recht van het land waar naartoe een werknemer is gedetacheerd op basis van de Detacheringsrichtlijn. De kwalificatie als bijzonder dwingend recht duidt op een voorrangsregel.

Een andere zienswijze is ook verdedigbaar. Artikel 9 lid 1 Rome I-Verordening omschrijft voorrangsregels als: 'bepalingen aan de inachtneming waarvan een land zoveel belang hecht voor de handhaving van zijn openbare belangen zoals zijn politieke, sociale of economische organisatie dat zij moet worden toegepast op elk geval dat onder de werkingssfeer valt ongeacht welk recht overeenkomstig deze verordening overigens van toepassing is op de overeenkomst'. Voorrangsregels zijn gericht op de instandhouding van de diversiteit aan nationale waarden. Het gaat om openbare belangen die een specifiek land van cruciaal belang acht voor zijn politieke, sociale of economische organisatie. Voorrangsregels verschillen aldus per lidstaat en het is de lidstaat die bepaalt of een regel van cruciaal belang is voor zijn politieke, sociale of economische organisatie. ${ }^{17}$ De aard van de Detacheringsrichtlijn is hiermee in strijd. De Detacheringsrichtlijn verplicht alle

15 Zie bijvoorbeeld HvJ EG 11 januari 2007, C-208/05 (ITC).

16 P.C. Vas Nunes, Social dumping: Europese hof slaat linksaf, TAO 2015/2, p. 47; M. Kullmann, Tijdelijke grensoverschrijdende detachering en gewoonlijk werkland: over de verhouding tussen de Rome I-Verordening en de Detacheringrichtlijn en de rol van de Handhavingsrichtlijn, NIPR 2015, p. 205; A.H. van Hoek, Private International Law: An Appropriate Means to Regulate Transnational Employment in the European Union?, Erasmus Law Review 2014/3; M. Houwerzijl, Regime shopping across (blurring) borders, in: A. Evju (red.), Regulating Transnational Labour Law in Europe: The quandaries of multilevel governance, Oslo: UiO 2014, p. 95-130; V. van den Eeckhout, Modellering van internationaal privaatrecht - Enkele ipr-technische aantekeningen bij het voorstel tot wijziging van de Detacheringsrichtlijn, NJBblog 2015. Ook de Nederlandse wetgever gaat hiervan uit, zie Kamerstukken II 2015/16, 34408, 3, p. 7.

Uiteraard binnen de grenzen van het Europese recht. 
lidstaten tot toepassing van de hardekern-arbeidsvoorwaarden in de situatie van tijdelijke detachering. Een dergelijke gemeenschapsconforme interpretatie van het begrip voorrangsregel is onverzoenlijk met het idee achter voorrangsregels, dat juist op diversiteit is gestoeld. De Detacheringsrichtlijn schaft in feite de noodzaak tot voorrangsregels op het niveau van de hardekern-arbeidsvoorwaarden af. ${ }^{18}$

Hoe zit het dan wel? De Grieks-Amerikaanse rechtsgeleerde Symeonides maakt een onderscheid tussen zelfstandige verwijzingsregels en voorrangsregels. ${ }^{19}$ Zelfstandige verwijzingsregels geven in de desbetreffende wet specifiek hun toepassingsbereik aan, terwijl voorrangsregels slechts het toepasselijke recht opzijzetten indien zij van belang zijn voor de handhaving van openbare belangen. De Detacheringsrichtlijn valt mijns inziens in de eerste categorie. Artikel 1 lid 1 luidt: 'Deze richtlijn is van toepassing op in een Lid-Staat gevestigde ondernemingen die in het kader van transnationale dienstverrichtingen (...) werknemers ter beschikking stellen op het grondgebied van een Lid-Staat.' De Detacheringsrichtlijn bepaalt haar eigen internationale bereik en functioneert daarmee onafhankelijk van de verwijzingssystematiek uit de Rome I-Verordening. ${ }^{20}$ Dat de Rome IVerordening voor overeenkomsten het toepasselijke recht bepaalt, staat daaraan niet in de weg. ${ }^{21}$ Artikel 23 Rome I-Verordening staat expliciet toe dat in Europese regelgeving voor bijzondere gebieden regels van internationaal privaatrecht worden vastgesteld. ${ }^{22}$ De Detacheringsrichtlijn is regelgeving in de zin van artikel 23 Rome I-Verordening. ${ }^{23}$

De kwalificatie als zelfstandige verwijzingsregel heeft een voordeel ten opzichte van de kwalificatie als voorrangsregel. Uit artikel 9 lid 3 Rome I-Verordening spreekt een grote beduchtheid om toepassing te geven aan voorrangsregels die

18 Eventueel kan worden betwist of dit geldt voor de hardekern-arbeidsvoorwaarden uit algemeen verbindend verklaarde cao's buiten de bouwsector. Nederland heeft de systematiek van algemeen verbindend verklaarde cao's ook buiten de bouwsector van toepassing verklaard, maar was daartoe op grond van de Detacheringsrichtlijn niet verplicht (artikel 3 lid 1 tweede streepje jo. artikel 10 tweede streepje Detacheringsrichtlijn). Op dit punt kunnen aldus verschillen tussen de lidstaten bestaan. Hetzelfde geldt met betrekking tot regels die verder gaan dan het geharmoniseerde minimum (zie HvJ EU 17 oktober 2013, C-184/12 (Unamar)). Op dit arrest wordt nader ingegaan in paragraaf 5.3 , zie met name noot 77 .

19 S.C. Symeonides, Codifying Choice of Law Around the World, Oxford University Press 2014, p. 294-300.

20 Vergelijk L.M. van Bochove, Overriding Mandatory Rules as a Vehicle for Weaker Party Protection in European Private International Law, ELR 2014, 3.

21 Deze benadering geldt niet voor Nederlandse regels met een eigen verwijzingssystematiek. Deze regels kunnen alleen via artikel 9 Rome I-Verordening de lex causau opzijzetten en moeten daarom altijd een openbaar belang kennen. De uitzondering van artikel 23 Rome I-Verordening ziet specifiek op Europese regels met een zelfstandig internationaal bereik.

22 Zie ook overweging 11 preambule Detacheringsrichtlijn.

23 In de literatuur wordt artikel 23 Rome I-Verordening wel genoemd als rechtvaardiging voor het feit dat de Detacheringsrichtlijn als voorrangsregel heeft te gelden. Dat lijkt me niet juist. De tekst van artikel 23 Detacheringsrichtlijn duidt erop dat in Europese verordeningen en richtlijnen speciale afwijkende verwijzingsregels kunnen worden vastgesteld; het artikel bepaalt niet dat aan artikel 9 Rome I-Verordening invulling kan worden gegeven. Met andere woorden: een regel werkt door via artikel 9 of (niet: en) via artikel 23 Rome I-Verordening. 
niet tot het rechtsstelsel van de bevoegde rechter behoren (lex fori). Als de Detacheringsrichtlijn een voorrangsregel is, kan een buitenlandse rechter de Nederlandse hardekern-arbeidsvoorwaarden slechts toepassen voor zover de bepalingen de tenuitvoerlegging van de overeenkomst onwettig maken ${ }^{24}$ en zelfs dan is hij niet tot toepassing verplicht. De werknemer zal een eventuele vordering daarom aanhangig moeten maken bij de rechter uit het tijdelijke werkland. ${ }^{25}$ Deze uitkomst bevreemdt. Hoofdregel in de Brussel Ibis-Verordening is dat de werknemer gedaagd dient te worden voor de rechter van zijn gewoonlijke werkland. ${ }^{26}$ Aan deze keuze ligt - net als bij artikel 8 Rome I-Verordening - de beschermingsgedachte ten grondslag. De weg naar de Nederlandse rechter is voor buitenlandse werknemers immers lastig vanwege onder meer taalbarrières en onbekendheid met het systeem. Daar komt bij dat gedetacheerde werknemers na voltooiing van het werk doorgaans zullen zijn teruggekeerd naar hun gewoonlijke werkland.

De restrictie van artikel 9 lid 3 Rome I-Verordening geldt niet bij de kwalificatie van de Detacheringsrichtlijn als zelfstandige verwijzingsregel. De werknemer heeft dan dus de keuze waar hij zijn vordering aanhangig maakt: bij de rechter van het tijdelijke of bij die van het gewoonlijke werkland. Ik ben me ervan bewust dat dit voordeel niet moet worden overschat. Het is de vraag of buitenlandse werknemers in de praktijk vaak zullen kiezen voor de rechter van het gewoonlijke werkland. Zo geldt als risico dat de buitenlandse rechter niet bekend is met de Nederlandse harde kern van arbeidsvoorwaarden. Bovendien kan de werknemer de Nederlandse (hoofd)opdrachtgever bij de buitenlandse rechter niet (althans lastig) hoofdelijk aansprakelijk stellen op grond van de artikelen 7:616a-c van het Burgerlijk Wetboek (BW). ${ }^{27}$ Tot slot is de buitenlandse rechter geen optie indien de procedure in samenspraak met de Nederlandse vakbond aanhangig wordt gemaakt. ${ }^{28}$ Een en ander neemt niet weg dat de buitenlandse werknemer bij de kwalificatie van de Detacheringsrichtlijn als zelfstandige verwijzingsregel een keuze heeft waar hij die anders niet had gehad.

24 Deze bewoordingen zijn door het Europees Parlement aan de Rome I-Verordening toegevoegd. Uit de documenten valt niet op te maken wat is bedoeld met het vereiste dat de bepalingen de tenuitvoerlegging onwettig maken. Verslag over het voorstel voor een verordening van het Europees Parlement en de Raad inzake het recht dat van toepassing is op verbintenissen uit overeenkomsten (Rome I) d.d. 21 november 2007, C6-0041-2005, COD(2005)0261, p. 29.

25 De werknemer is hiertoe bevoegd op grond van artikel 6 Detacheringsrichtlijn.

26 Zie artikel 21 Brussel Ibis-Verordening.

27 Nederland beschouwt de artikelen 7:616a-c BW als voorrangsregels en deze artikelen zijn als zodanig dus wel onderworpen aan de restricties van artikel 9 lid 3 Rome I-Verordening. Zie Kamerstukken II 2014/15, 34108, 3, p. 35. Bij de kwalificatie van de artikelen 7:616a-c BW als voorrangsregels zijn overigens wel vraagtekens te plaatsen. Deze discussie laat ik hier verder buiten beschouwing.

28 De Nederlandse vakbond dient een eventuele procedure jegens de buitenlandse werkgever wegens niet-nakoming van een toepasselijke algemeen verbindend verklaarde cao aanhangig te maken bij de Nederlandse rechter op grond van artikel 5 Rome I-Verordening. 


\section{Het mijnenveld van het begrip tijdelijkheid}

\subsection{Duur van de tewerkstelling}

De Detacheringsrichtlijn is van toepassing op de tijdelijke detachering van werknemers naar een andere lidstaat. Artikel 1 verstaat onder tijdelijk 'een werknemer die gedurende een bepaalde periode werkt op het grondgebied van een Lid-Staat die niet de Staat is waar die werknemer gewoonlijk werkt'. Uit de tekst blijkt niet welke termijn is bedoeld met de woorden 'gedurende een bepaalde periode'. De Kantonrechter Groningen beschouwde in een uitspraak uit 2015 een tewerkstelling van een jaar vanwege de duur als niet-tijdelijk. ${ }^{29}$ Dit lijkt mij onjuist. De Detacheringsrichtlijn koppelt tijdelijkheid niet aan een vaststaande periode. De Rome I-Verordening doet dit evenmin. De preambule van de Rome I-Verordening vermeldt in overweging 36 dat het verrichten van arbeid in een ander land als tijdelijk heeft te gelden 'wanneer van de werknemer wordt verwacht dat hij na voltooiing van zijn taak in het buitenland opnieuw arbeid in het land van herkomst verricht'. Het gaat om de verwachting tot terugkeer. Uiteraard is de duur een belangrijke indicatie, maar het element als zodanig is niet doorslaggevend, zoals de Kantonrechter Groningen meent. De Handhavingsrichtlijn bevestigt deze zienswijze en benoemt in artikel 4 lid 3 de duur van tewerkstelling als één van meer elementen op basis waarvan tijdelijkheid wordt bepaald.

De verwachting tot terugkeer is gerelateerd aan de intentie van de werkgever. De dienstverlener maakt gebruik van de vrijheid van diensten en besluit in het verlengde daarvan met welke verwachting hij zijn personeel naar het buitenland detacheert. Deze constatering betekent overigens niet dat aan het vereiste van tijdelijkheid is voldaan zodra de werkgever in de detacheringsovereenkomst aangeeft dat de werknemer na afloop van het project terugkeert. Wat van de werknemer wordt verwacht, wordt volgens de Handhavingsrichtlijn bepaald op basis van alle feitelijke omstandigheden die voor het werk alsmede de situatie van de werknemer kenmerkend zijn. Naast de duur van de detachering is relevant in hoeverre de werkgever tijdens de detachering zorg draagt voor kost en accommodatie, de tijdvakken waarin een (andere) werknemer hetzelfde werk verrichtte, de aard van de activiteiten en of de werknemer daadwerkelijk terugkeert na voltooiing van het werk. ${ }^{30}$ De elementen maken duidelijk dat niet alleen de intentie van de werkgever voorafgaand aan de detachering, maar ook de daadwerkelijke uitvoering relevant is bij de beoordeling van wat tijdelijk is. ${ }^{31}$

In het voorstel tot aanpassing van de Detacheringsrichtlijn gooit de Europese Commissie het over een andere boeg. Volgens de Europese Commissie kan bij een verwachte of effectieve duur van twee jaar geen sprake meer zijn van tijdelijkheid. Een vaste termijn van twee jaar sluit aan bij de Verordening betreffende de coördinatie van de socialezekerheidsstelsels en leidt tot meer rechtszekerheid. Maar

29 Ktr. Groningen 4 maart 2015, JAR 2015/85 (FNV/Waterhuizen \& Shipyard).

30 Zie over de criteria van artikel 4 lid 2 Handhavingsrichtlijn meer uitgebreid Kullmann 2015, p. 213-214.

31 Lastig is wel dat doorgaans pas na geruime tijd kan worden vastgesteld of sprake is van tijdelijkheid. Dit geldt zeker voor het element of de werknemer daadwerkelijk terugkeert na voltooiing van het project. 
er kleven ook nadelen aan. Het risico bestaat dat de termijn van twee jaar in de rechtspraak een doorslaggevende status verkrijgt (het is immers eenvoudig vast te stellen), zodat een tewerkstelling van minder dan twee jaar al snel het predicaat 'tijdelijk' opgeplakt krijgt. Dienstverleners kunnen hierop inspelen. ${ }^{32}$ Dit geldt temeer omdat bij onduidelijkheid over de duur van de tewerkstelling het recht van het ontvangstland pas na twee jaar - en dus niet met terugwerkende kracht - van toepassing wordt. Overweging 8 van de preambule bij het voorstel tot aanpassing van de Detacheringsrichtlijn bepaalt: 'Dit [het recht van het gastland: FL] moet van toepassing zijn vanaf het begin van de terbeschikkingstelling wanneer die voor meer dan 24 maanden is gepland en vanaf de eerste dag na de 24 maanden wanneer de terbeschikkingstelling daadwerkelijk langer duurt.' Hiermee wint de intentie van de werkgever (en dus de mogelijkheid tot manipulatie) aan kracht ten opzichte van de feitelijke uitvoering.

\subsection{Ontbreken van een gewoonlijk werkland}

Artikel 2 Detacheringsrichtlijn verstaat onder een ter beschikking gestelde werknemer: 'iedere werknemer die gedurende een bepaalde periode werkt op het grondgebied van een Lid-Staat die niet de Staat is waar die werknemer gewoonlijk werkt'. De tijdelijkheid is aldus gerelateerd aan het bestaan van een gewoonlijk werkland. Maar wat geldt als er geen gewoonlijk werkland valt aan te wijzen? ${ }^{33}$ Dit doet zich voor in de situatie dat de werknemer zijn werkzaamheden steeds afwisselend voor een bepaalde periode in een andere lidstaat verricht. Dit komt veel voor in de bouwsector. ${ }^{34}$ Artikel 8 Rome I-Verordening verwijst bij het ontbreken van een gewoonlijk werkland voor het objectief toepasselijke recht naar de vestiging die de werknemer in dienst heeft genomen (lid 3). Bovendien kan uit het geheel der omstandigheden blijken dat de arbeidsovereenkomst nauwer verbonden is met een ander land, waardoor het recht van dat land het objectief toepasselijke recht is (lid 4). Deze laatste bepaling kan ook opgaan indien er wel een gewoonlijk werkland valt aan te wijzen. ${ }^{35}$

32 Wel geldt dat de vervanging van de werknemer op zichzelf niet voldoende is om de termijn van twee jaar te doorbreken. Als het om dezelfde taak gaat, worden de periodes van de tewerkstelling bij elkaar opgeteld. Dit is vastgelegd in artikel 2 bis lid 2 Voorstel tot aanpassing van de Detacheringsrichtlijn.

33 In de verhouding tussen artikel 8 lid 2 en lid 3 moet het criterium 'gewoonlijk werkland' ruim worden uitgelegd. Het Hof van Justitie oordeelde dat de bescherming van de werknemer het meest is gebaat als er een gewoonlijk werkland valt aan te wijzen. De werknemer oefent namelijk zijn economische en sociale functie in het werkland uit en zijn arbeid ondergaat in die staat de invloed van het politieke en bedrijfsklimaat. Zie HvJ EU 15 maart 2011, C-29/10 (Koelzsch/ Luxemburg), punt 43; HvJ EU 15 december 2011, C-384/10 (Voogsgeerd/Navimer), punt 35. De arresten hebben betrekking op de uitleg van artikel 6 EVO-Verdrag, maar gelden ook in verhouding tot de haast gelijkluidende tekst van artikel 8 Rome I-Verordening.

34 Artikel 8 lid 2 Rome I-Verordening sluit voor het gewoonlijke werkland aan bij het land waar of vanuit waar de werkzaamheden worden verricht. Deze zinsnede is een codificatie van de rechtspraak van het Hof van Justitie inzake de transportsector. Voor de bouwsector biedt deze zinsnede evenwel geen oplossing omdat de werknemers niet vanuit een bepaalde lidstaat hun werkzaamheden verrichten, maar steeds voor een afwisselende duur in een andere lidstaat werkzaam zijn, in welke lidstaat zij ook hun instructies en dergelijke ontvangen.

35 HvJ EU 12 september 2013, JAR 2013/250, m.nt. Laagland (Boedeker/Schlecker). 
De vraag rijst of de Detacheringsrichtlijn buiten werking blijft indien artikel 8 lid 3 of lid 4 Rome I-Verordening het objectief toepasselijke recht bepaalt. In de Rome I-Verordening levert het begrip tijdelijk slechts bij de vaststelling van het gewoonlijke werkland discussie op. Hoewel de Detacheringsrichtlijn hierbij aansluit, is de opzet van de Detacheringsrichtlijn een andere. De Detacheringsrichtlijn geeft de werknemer recht op de hardekern-arbeidsvoorwaarden zoals die gelden in het tijdelijke werkland. Reden is de werknemersbescherming, maar ook het tegengaan van oneerlijke concurrentie. Hoewel strikt genomen de Detacheringsrichtlijn niet van toepassing lijkt indien een gewoonlijk werkland ontbreekt, gelden de doelstellingen net zo goed indien de verwijzingsregel van artikel 8 lid 3 of lid 4 Rome I-Verordening het objectief toepasselijke recht bepaalt. Ik sta daarom een analoge toepassing voor. Een andere uitleg zou ertoe leiden dat de werkgever zich kan vestigen in het land met het laagste loonniveau en vanuit dat land de werknemers tegen de aldaar geldende regels roulerend binnen de Europese Unie kan tewerkstellen zonder dat aan de werknemers de bescherming van de Detacheringsrichtlijn toekomt. ${ }^{36}$ Deze uitkomst lijkt me niet beoogd.

Lastig is wel hoe bij roulerende detachering de tijdelijkheid wordt bepaald. Waar naartoe moet de werknemer terugkeren? De Detacheringsrichtlijn spreekt specifiek over het gewoonlijke werkland, en de Handhavingsrichtlijn acht relevant of de werknemer na de beëindiging van de werkzaamheden terugkeert naar de lidstaat vanwaar hij is gedetacheerd of waar hij wordt geacht weer te gaan werken [cursivering: FL]. Bij roulerende detachering gaat de werknemer doorgaans aan de slag in een andere (nieuwe) lidstaat. Toch acht ik dit probleem niet onoverkomelijk. Ik kan me voorstellen dat bij roulerende detachering meer belang toekomt aan de overige elementen die de Handhavingsrichtlijn noemt, zoals de duur van de detachering, het feit dat de werkgever het vervoer, de kost en inwoning voor zijn rekening neemt en de aard van de activiteiten die maakt dat de werknemer veelvuldig in verschillende landen op projecten werkzaam is.

\subsection{Dienstverband voor duur detachering}

Het komt voor dat de werknemer slechts bij de werkgever in dienst treedt voor de duur van de detachering. De Kantonrechter Utrecht meende in 2015 dat deze omstandigheid aan tijdelijkheid in de weg stond. ${ }^{37}$ De zaak betrof de detachering van onder meer Portugese werknemers naar Nederland. De werknemers waren via een Engels uitzendbureau aan Avenue2 (de Nederlandse hoofdaannemer) ter beschikking gesteld om te werken aan de A2-tunnel. Met de Portugese werkne-

36 Ik ga er hierbij van uit dat artikel 8 lid 4 Rome I-Verordening niet opgaat. Toepassing van artikel 8 lid 4 Rome I-Verordening is lastig, omdat de werknemers steeds ergens anders werkzaam zijn. Eventueel kunnen de werknemers nog via artikel 9 Rome I-Verordening een beroep doen op de harde kernarbeidsvoorwaarden uit het (steeds wisselende) tijdelijke werkland.

37 Ktr. Utrecht (kort geding) 18 maart 2015, JAR 2015/83, m.nt. Laagland; Ktr. Utrecht (bodemprocedure) 22 juli 2015, JAR 2015/203, m.nt. Franssen. Ook M.S. Houwerzijl, Verschillen in toepasselijk arbeidsrecht bij tijdelijke en structurele arbeidsmigratie, in: H. Verscheuren \& M.S. Houwerzijl, Toepasselijk arbeidsrecht over de grenzen heen, Deventer: Kluwer 2009, p. 181, meent dat de Detacheringsrichtlijn niet opgaat indien de werknemer slechts in dienst is gekomen om te worden uitgezonden. Anders: Vas Nunes 2015, p. 55 en mijn noot in JAR 2015/83. 
mers was overeengekomen dat hun arbeidsovereenkomst met het uitzendbureau zou eindigen tegelijk met de voltooiing van het werk aan de A2-tunnel. De Kantonrechter in zowel kort geding als bodemprocedure overwoog dat de Detacheringsrichtlijn niet van toepassing was. Er kon geen sprake zijn van tijdelijkheid nu de werknemers slechts voor het werk aan de A2-tunnel bij het uitzendbureau in dienst waren getreden. Nederland was daarom te beschouwen als het gewoonlijke werkland.

Voor deze strikte uitleg van tijdelijkheid spreekt dat de Rome I-Verordening in artikel 8 lid 2 uitgaat van de arbeidsovereenkomst tussen de werkgever en de werknemer. Indien de werknemer binnen dat desbetreffende dienstverband tijdelijk zijn arbeid in het buitenland verricht, treedt geen wijziging op in het toepasselijke recht. Overweging 36 van de preambule bij de Rome I-Verordening wijst in dezelfde richting. De tweede zin luidt: 'Het sluiten van een nieuwe arbeidsovereenkomst met de oorspronkelijke werkgever of met een werkgever die tot dezelfde groep van bedrijven behoort als de oorspronkelijke werkgever, mag niet beletten dat de werknemer geacht wordt zijn arbeid tijdelijk in een ander land te verrichten.' Dit betekent a contrario dat wanneer de werknemer met een onafhankelijke derde een nieuwe arbeidsovereenkomst sluit, het land waar hij gaat werken vanaf de eerste werkdag als het gewoonlijke werkland geldt. ${ }^{38}$ Hoe kort of lang de tewerkstelling ook duurt en ongeacht het land waar de werknemer voor die tijd werkzaam was.

Duidelijk is dat de Rome I-Verordening met tijdelijkheid het oog heeft op een tewerkstelling in het buitenland binnen hetzelfde dienstverband. Maar geldt dezelfde uitleg voor het begrip tijdelijkheid in de Detacheringsrichtlijn? Ik verwacht van niet. De Detacheringsrichtlijn is gebaseerd op de vrijheid van diensten en stelt in overweging 5 het bevorderen van grensoverschrijdende dienstverrichting voorop. Anders dan bij de uitleg van artikel 8 Rome I-Verordening is bij de uitleg van de Detacheringsrichtlijn daarom naast de werknemersbescherming de vrijheid van diensten van belang. ${ }^{39}$ Indien wordt aangenomen dat de Detacheringsrichtlijn niet geldt bij een arbeidsovereenkomst aangegaan voor de duur van de detachering, dan worden buitenlandse dienstverleners aangetast in hun capaciteit de dienst te verrichten. De buitenlandse dienstverlener kan immers minder makkelijk nieuwe werknemers aannemen bij het binnenhalen van een nieuwe klus; voor deze groep geldt de Detacheringsrichtlijn niet. ${ }^{40}$ Rechtvaardigt de werknemersbescherming deze belemmering van de vrijheid van diensten? Ik verwacht van niet. De werknemers die slechts voor de klus zijn aangenomen, verrichten hetzelfde werk voor dezelfde duur als de werknemers die reeds bij de dienstverle-

38 Deze uitleg is in lijn met het discriminatieverbod zoals dat volgt uit de vrijheid van werknemers.

39 De Detacheringsrichtlijn noemt in de preambule weliswaar het EVO-Verdrag (thans de Rome IVerordening), maar er wordt slechts overwogen dat het EVO-Verdrag in de lidstaten van kracht is. Er staat niet dat de Detacheringsrichtlijn in het licht van de Rome I-Verordening moet worden uitgelegd.

40 Er wordt doorgaans van uitgegaan dat bij het ontbreken van tijdelijkheid de objectieve bepalingen uit het recht van het ontvangstland op de arbeidsovereenkomst van toepassing zijn op basis van artikel 8 lid 2 Rome I-Verordening. Hierover is discussie mogelijk (zie paragraaf 4). 
ner in dienst waren, en op de laatste groep is de Detacheringsrichtlijn ook van toepassing.

Dat tijdelijkheid een verschillende betekenis heeft in de Rome I-Verordening en de Detacheringsrichtlijn is mijns inziens niet problematisch. De Detacheringsrichtlijn kent zoals gezegd een eigen verwijzingssystematiek, en uit artikel 23 Rome I-Verordening volgt dat de Detacheringsrichtlijn op de Rome I-Verordening prevaleert. Met andere woorden: als de Detacheringsrichtlijn opgaat, komt men aan de Rome I-Verordening niet toe.

\section{Permanente detachering en wat dan?}

\subsection{De exceptieclausule van artikel 8 lid 4 Rome I-Verordening}

Bij permanente detachering kan het zijn dat de buitenlandse dienstverlener gebruikmaakt van de vrijheid van diensten dan wel de vrijheid van vestiging. Het permanent detacheren van werknemers naar een andere lidstaat betekent op zichzelf niet dat de vrijheid van vestiging in werking treedt. Het Hof van Justitie bepaalt het onderscheid tussen de vrijheid van dienstverlening en de vrijheid van vestiging op basis van de duur, maar ook op basis van de regelmaat, de frequenties en de continuïteit van de dienstverlening. ${ }^{41}$ Het voorstel tot aanpassing van de Detacheringsrichtlijn is hiermee in lijn. ${ }^{42}$ Voor de vraag naar het toepasselijke recht maakt het geen verschil. Bij de totstandkoming van de Handhavingsrichtlijn bestond discussie over welk recht zou moeten gelden bij permanente detachering. Verschillende opties passeerden de revue. ${ }^{43}$ Uiteindelijk is besloten aan te sluiten bij de systematiek van de Rome I-Verordening. Daarbij is niet relevant of de dienstverlener gebruikmaakt van de vrijheid van dienstverlening of de vrijheid van vestiging. ${ }^{4}$

Het voorstel tot aanpassing van de Detacheringsrichtlijn gaat ervan uit dat bij permanente detachering steeds het recht van het gewoonlijke werkland op de

41 HvJ EG 7 september 2004, C-456/02 (Trojani); HvJ EG 30 november 1995, C-55/94 (Gebhard), punt 27; HvJ EG 11 december 2003, C-215/01 (Schnitzer), punten 28-30.

42 Zie overweging 8 preambule Voorstel tot aanpassing van de Detacheringsrichtlijn. Hier is bepaald: 'Dit voorschrift doet geen afbreuk aan het recht van ondernemingen die werknemers op het grondgebied van een andere lidstaat ter beschikking stellen om ook (de) vrijheid van dienstverrichting in te roepen in omstandigheden waarbij de terbeschikkingstelling langer dan 24 maanden duurt.'

43 Meer uitgebreid Van Hoek 2014, p. 168.

44 Het zou eventueel verschil kunnen maken indien op grond van artikel 8 Rome I-Verordening geen gewoonlijk werkland kan worden aangewezen en voor het objectief toepasselijke recht wordt aangesloten bij het recht van de vestiging die de werknemer in dienst heeft genomen. Maar ook hierover valt te twisten, nu het doorgaans niet de Nederlandse maar de buitenlandse vestiging van de werkgever zal zijn die zich bezighoudt met de werving en selectie van buitenlandse werknemers. 
arbeidsovereenkomst van toepassing zal zijn. ${ }^{45}$ Ook Nederlandse rechters trekken bij het ontbreken van tijdelijkheid zonder meer de conclusie dat Nederland het gewoonlijke werkland is. ${ }^{46}$ Deze benadering is niet altijd juist. Het Hof van Justitie overwoog in het arrest Boedeker/Schlecker uit 2013 dat ook bij het bestaan van een gewoonlijk werkland relevantie toekomt aan de exceptieclausule van artikel 8 lid 4 Rome I-Verordening. ${ }^{47}$ Belangrijke factoren voor de aanknoping bij de exceptieclausule zijn: het land waar de werknemer belastingen en heffingen op inkomsten uit arbeid betaalt, het land waar hij is aangesloten bij de sociale zekerheid en de verschillende pensioen-, ziektekostenverzekerings- en invaliditeitsregelingen, de criteria betreffende de vaststelling van het salaris en de andere arbeidsvoorwaarden die op de arbeidsovereenkomst van toepassing zijn (denk aan een cao of enig ander arbeidsvoorwaardendocument). ${ }^{48}$ Wijzen al deze factoren naar een bepaald land, dan schuift het recht van dit land het recht van het gewoonlijke werkland terzijde.

Mocht men aannemen dat het aangaan van een arbeidsovereenkomst voor de duur van de detachering buiten het toepassingsbereik van de Detacheringsrichtlijn valt (hetgeen ik betwist; zie paragraaf 3.3), dan staat dus niet automatisch vast dat de dwingende bepalingen van het Nederlandse recht de arbeidsovereenkomst beheersen. In die situatie wijzen de door het Hof van Justitie genoemde elementen vrij snel naar een ander land dan Nederland. Denk aan de Pool die voor een periode van een halfjaar in dienst treedt bij een Pools uitzendbureau om in Nederland te werken, zijn kost en inwoning betaald krijgt en direct na afloop van de klus terugkeert naar Polen. In het licht van het Boedeker/Schlecker-arrest lijkt mij deze Pool het nauwst verbonden te zijn met Polen, ondanks Nederland als gewoonlijk werkland. Dit betekent dat de arbeidsovereenkomst alsnog aan de dwingende bepalingen van het Poolse recht is onderworpen.

Eenzelfde redenering gaat mijns inziens op bij permanente dienstverlening waarbij steeds nieuwe werknemers voor een tijdelijke duur worden ingezet om het(zelfde) werk te verrichten. Het antwoord van het Hof van Justitie in de zaak Boedeker/Schlecker maakt duidelijk dat zelfs sprake kan zijn van een nauwere band met een ander land indien het gaat om een langdurige tewerkstelling van

Overweging 6 Voorstel tot aanpassing van de Detacheringsrichtlijn. Deze aanname wordt onderstreept op p. 7. Interessant is de vraag in hoeverre deze uitkomst zich verhoudt tot de vrijheid van diensten dan wel de vrijheid van vestiging. Ik verwacht dat de Rome I-Verordening kan worden gezien als een nadere invulling van de belemmeringen die zijn toegestaan op de vrijheid van diensten dan wel de vrijheid van vestiging, maar zeker ben ik niet. Vergelijk S. Deakin, Regulatory Competition in Europe after Laval, working paper for Reflexive Governance in the Public Interest Fundamental Rights (REFGOV-FR-18), p. 32-33.

46 Zie bijvoorbeeld Ktr. Utrecht (kort geding) 18 maart 2015, JAR 2015/83, m.nt. Laagland; Ktr. Utrecht (bodemprocedure) 22 juli 2015, JAR 2015/203, m.nt. Franssen.

47 HvJ EU 12 september 2013, JAR 2013/250, m.nt. Laagland (Boedeker/Schlecker); AR-Updates 2013-0705, m.nt. Even. Het arrest heeft betrekking op artikel 6 EVO-Verdrag, maar is door de haast gelijkluidende tekst ook relevant bij de toepassing van artikel 8 Rome I-Verordening.

48 Het beschermingsbeginsel moet formeel worden uitgelegd; het gaat er niet om toepassing te verlenen aan het recht dat de werknemer de meeste voordelen biedt (punt 34). Dat het Nederlandse recht voor de buitenlandse werknemer dus gunstiger is, doet niet ter zake bij de uitleg van de artikel 8 Rome I-Verordening en de beoordeling of de exceptieclausule opgaat. 
dezelfde werknemer. Mevrouw Boedeker was meer dan vijftien jaar vanuit Duitsland in Nederland tewerkgesteld. De lange duur van de detachering sloot een nauwere band met een ander land evenwel niet uit, omdat alle overige elementen naar Duitsland verwezen. ${ }^{49}$

\subsection{Toepassing hardekern-arbeidsvoorwaarden uit wet en cao}

Bij toepassing van artikel 8 lid 4 Rome I-Verordening is de arbeidsovereenkomst alsnog onderworpen aan de dwingende bepalingen van het herkomstland, maar mist de werknemer de bescherming van de Detacheringsrichtlijn. Lidstaten zijn in dat geval niet verplicht de hardekern-arbeidsvoorwaarden op de arbeidsovereenkomst toe te passen. In Nederland gelden de wettelijke hardekern-arbeidsvoorwaarden echter - los van de Detacheringsrichtlijn - als voorrangsregel in de zin van artikel 9 Rome I-Verordening. ${ }^{50}$ Permanent gedetacheerde werknemers kunnen op deze bepalingen dus alsnog een beroep doen. De situatie is minder duidelijk met betrekking tot de hardekern-arbeidsvoorwaarden uit algemeen verbindend verklaarde cao's. De vraag rijst of bepalingen uit algemeen verbindend verklaarde cao's zich kwalificeren als regels waarvan niet kan worden afgeweken (artikel 8 Rome I-Verordening) of als regels van openbare orde (artikel 9 Rome IVerordening). Het onderscheid is relevant. Bij toepassing via artikel 8 Rome IVerordening kan de permanent gedetacheerde werknemer geen beroep doen op de algemeen verbindend verklaarde cao indien de exceptieclausule van artikel 8 lid 4 naar het recht van een ander land dan Nederland verwijst. De werknemer heeft deze mogelijkheid wel bij toepassing via artikel 9 Rome I-Verordening omdat dan het objectief toepasselijke recht wordt doorkruist. Uiteraard is wel vereist dat de buitenlandse werkgever valt onder de werkingssfeer van de algemeen verbindend verklaarde cao (zie over dit onderwerp meer uitgebreid paragraaf 5.1). Bepalingen in algemeen verbindend verklaard cao's zijn naar hun aard regels van privaat- en geen regels van publiekrecht. De cao wordt afgesloten tussen en gehandhaafd door private partijen en omvat voor het merendeel regels die zien op de onderlinge rechtsverhouding tussen werknemer en werkgever. Hier kan tegenin worden gebracht dat het algemeen verbindend verklaren van cao's in Nederland publiekrechtelijke doelen dient: het beschermen van werknemers en het tegengaan van oneerlijke concurrentie. Ook in de schaarse Nederlandse rechtspraak zijn algemeen verbindend verklaarde cao's vanwege hun publiekrechtelijke doelstelling als voorrangsregels gekwalificeerd. ${ }^{51}$ Dat wijst alsnog in de richting van voorrangsregels. ${ }^{52}$

Indien wordt aangenomen dat het algemeen verbindend verklaren van cao's een publiekrechtelijk doel dient (wat ik verwacht), betekent deze vaststelling nog niet

49 In de casus die leidde tot het arrest was bijzonder dat mevrouw Boedeker gedurende haar tewerkstelling in het buitenland in Duitsland was blijven wonen.

50 Nu bestaat geen discussie of de bepalingen hebben te gelden als voorrangsregels of als zelfstandige verwijzingsregels. De Detacheringsrichtlijn mist toepassing in deze situatie.

51 Ktr. Amsterdam 27 november 1989, NJ 1991/143; Ktr. Den Haag 4 maart 1986, NIPR 1987/127; Ktr. Den Haag 8 september 1992, Prg 992/3744.

52 Vergelijk A.A.H. van Hoek, Internationale mobiliteit van werknemers (diss. UvA), Den Haag: Sdu 2000, p. 498. 
dat alle bepalingen uit de cao ook voorrangsregels zijn. Het Hof van Justitie overwoog in het arrest Commissie/Luxemburg dat niets de opvatting rechtvaardigt dat bepalingen onder het begrip openbare orde vallen enkel omdat zij uit collectieve arbeidsovereenkomsten voortvloeien. ${ }^{53}$ Het moet volgens A-G Trstenjak in zijn conclusie bij het arrest gaan om bepalingen die gezien hun aard en doel voldoen aan de dwingende eisen van algemeen belang. ${ }^{54}$ Tevens mag de vrijheid van diensten (dan wel de vrijheid van vestiging) niet worden belemmerd. Deze toets moet per cao-bepaling worden uitgevoerd. Ik verwacht dat de toets zeker positief uitvalt voor de cao-bepalingen die zien op de hardekern-arbeidsvoorwaarden uit de Detacheringsrichtlijn. Het ligt niet voor de hand dat het Hof van Justitie de kwalificatie als voorrangsregels van deze cao-bepalingen afwijst nu deze cao-bepalingen bij een tijdelijke detachering via de Detacheringsrichtlijn wel het objectief toepasselijke recht terzijde schuiven. ${ }^{55}$

\section{De Detacheringsrichtlijn: contracting, intra-concernuitlening en uitzending}

\subsection{Grensoverschrijdende detachering}

De Detacheringsrichtlijn onderscheidt drie vormen van detachering: contracting (type a), ${ }^{56}$ intra-concernuitlening (type b) en uitzending (type c). Van grensoverschrijdende detachering is sprake indien een werknemer op basis van een van de drie detacheringsvormen wordt tewerkgesteld op het grondgebied van een andere lidstaat dan waar hij gewoonlijk werkt. In de meeste beroepsgroepen doen zich geen problemen voor en is eenvoudig vast te stellen in welke lidstaat de werknemer het werk verricht. Dat ligt anders in de internationale transportsector. ${ }^{57}$ In dat geval besteedt een Nederlands transportbedrijf (een deel van) het werk uit aan een buitenlands transportbedrijf dat zijn eigen werknemers inzet om de ritten in Europa te rijden. Het gaat om een type a-detachering. De vraag rijst of deze

HvJ EU 19 juni 2008, C-319/06 (Commissie/Luxemburg), punt 66. Het oordeel van het Hof had betrekking op de exceptie van openbare orde als neergelegd in artikel 3 lid 10 Detacheringsrichtlijn, maar geldt naar ik verwacht ook voor de exceptie van openbare orde als neergelegd in artikel 9 Rome I-Verordening.

54 A-G Trstenjak in zijn conclusie van 13 september 2007 bij C-319/06, punten 44-45.

55 De algemeen verbindend verklaarde cao-bepalingen die geen voorrangsregels zijn, blijven onderworpen aan het regime van artikel 8 Rome I-Verordening, zodat de buitenlandse werknemer bij toepassing van de exceptieclausule daaraan geen rechten kan ontlenen. Dit is uiteraard anders indien Nederland op basis van artikel 8 lid 2 Rome I-Verordening het gewoonlijke werkland is en de exceptieclausule niet opgaat.

56 Contracting is geen juridische term, maar wordt in de Nederlandse literatuur gebruikt indien het gaat om het uitbesteden van werk aan een derde die het werk verricht met zijn eigen werknemers, die werken onder zijn leiding en gezag. Ik hanteer deze term in de rest van het artikel ter aanduiding van de type a-detachering uit de Detacheringsrichtlijn.

57 Zie over detachering in de internationale transportsector meer uitgebreid E.J.A. Franssen, Concurrerende arbeidsvoorwaarden in het internationale wegtransport, Tijdschrift Vervoer en Recht 2016/2, p. 37-48. 
chauffeurs in een andere lidstaat dan hun gewoonlijke lidstaat werkzaam zijn. ${ }^{58}$ De vraag is relevant, omdat de buitenlandse werknemer bij Nederland als tijdelijk werkland recht heeft op de Nederlandse hardekern-arbeidsvoorwaarden. Is Nederland niet het tijdelijke werkland, dan beheerst het recht van het gewoonlijke werkland de arbeidsovereenkomst en heeft de buitenlandse werknemer slechts recht op de aldaar geldende (hardekern-)arbeidsvoorwaarden zoals het minimumloon.

Het Hof Arnhem-Leeuwarden beantwoordde de vraag ontkennend in een arrest van 17 mei 2016. ${ }^{59}$ Een Nederlands internationaal transportbedrijf had een verworven opdracht tot vervoer van goederen in Europa uitbesteed aan buitenlandse vennootschappen, waaronder twee aan het transportbedrijf gelieerde vennootschappen in Roemenië en Litouwen. De cao Beroepsgoederenvervoer was algemeen verbindend verklaard. ${ }^{60}$ De cao kende een charterbepaling die kort gezegd inhield dat de Nederlandse opdrachtgever gehouden was in overeenkomsten van onderaanneming, die in of vanuit Nederland gevestigde ondernemingen van de opdrachtgever werden uitgevoerd, te bedingen dat de onderaannemer aan zijn werknemers de basisarbeidsvoorwaarden van de cao zou toekennen wanneer dat voortvloeide uit de Detacheringsrichtlijn. De zinsnede 'die in of vanuit de in Nederland gevestigde onderneming van werkgever worden uitgevoerd' vertoont gelijkenis met het vereiste dat het werk in een andere lidstaat (hier: Nederland) dan het oorspronkelijke werkland moet worden verricht. Het Hof bespreekt beide elementen ook in het verlengde van elkaar. ${ }^{61}$ Volgens het Hof is niet aan de charterbepaling voldaan nu de buitenlandse vennootschappen zelfstandig opererende vennootschappen waren, de chauffeurs die de ritten uitvoerden bij deze vennootschappen in dienst waren, de opdrachten ritten waren die buiten Nederland in Europa werden gelost en de chauffeurs op een enkele rit vrachten van meerdere opdrachtgevers vervoerden. De formulering doet vermoeden dat tevens geen sprake was van grensoverschrijdende detachering.

Het Hof Arnhem-Leeuwarden maakte niet duidelijk op basis waarvan het beoordeelde of sprake was van grensoverschrijdende detachering. Mijns inziens zijn richtinggevend de elementen die het Hof van Justitie noemde in het arrest Koelzsch uit 2011. ${ }^{62}$ Het Hof van Justitie overwoog dat bij het bepalen van het gewoonlijke werkland in de internationale transportsector bepalend is vanuit welke lidstaat de chauffeur zijn transportopdrachten aanvangt, werkinstructies krijgt, zijn werk organiseert, waar de vrachtwagens zich bevinden, waar het werk

58 Het gewoonlijke werkland wordt bepaald op basis van de criteria uit het arrest van het Hof van Justitie inzake Koelzsch/Luxemburg van 11 maart 2011, C-29/10, ECLI:EU:C:2011:151. Dit is doorgaans niet Nederland.

59 Hof Arnhem-Leeuwarden 17 mei 2016, JAR 2016/147, m.nt. Fransen (FNV/Vos Transport).

60 Vos dreef vanuit twee vestigingen een onderneming gericht op (inter)nationaal vervoer. Vos Limburg viel onder de cao Beroepsgoederenvervoer over de weg. Vos Transport was gebonden aan de cao Goederenvervoer van Nederland en viel onder de dispensatieregeling van de cao Beroepsgoederenvervoer over de weg. De cao Goederenvervoer van Nederland kende evenwel een gelijkluidende charterbepaling.

61 Zie r.o. 5.20.

62 HvJ EU 11 maart 2011, C-29/10, ECLI:EU:C:2011:151 (Koelzsch/Luxemburg). 
hoofdzakelijk wordt verricht, de goederen worden gelost en naar welke plaats de chauffeur na zijn ritten terugkeert. Deze elementen kunnen tevens als aanknopingspunten gelden bij de vraag of de werkzaamheden tijdelijk in een ander land dan het gewoonlijke werkland worden verricht. Het zou vreemd zijn als de chauffeurs wel in Nederland werken als zij in dienst van een Nederlands bedrijf de ritten verrichten, maar dit niet het geval is als dezelfde ritten worden gereden vanuit een dienstverband met een buitenlandse dienstverrichter. De plaats van werkzaamheden is dezelfde en dat is waar het om gaat.

Het uiteindelijke oordeel van het Hof Arnhem-Leeuwarden van 17 mei 2016 past in deze lijn. In een arrest van het Hof Den Bosch van 24 mei 2016 gold Nederland wel als tijdelijk werkland. ${ }^{63}$ Ditmaal waren de (inter)nationale ritten uitbesteed aan een gelieerd Pools bedrijf. Aan de overweging van het Hof Den Bosch kan echter niet te veel belang worden gehecht: het Nederlandse internationale transportbedrijf had weinig tot geen inhoudelijk verweer gevoerd. Maar als klopt wat de FNV aanvoerde - dat de Poolse chauffeurs hun ritten in en vanuit Nederland reden en slechts sporadisch in Polen kwamen -, meen ik dat de FNV een punt had. ${ }^{64}$

Probleem bij onderaanneming in de internationale transportwereld blijft dat het gaat om vervoersopdrachten in Europa en dat de chauffeurs in dienst van de buitenlandse dienstverrichter doorgaans niet naar Nederland zullen terugkeren na afloop van het werk. Dit geldt temeer indien de werknemers verschillende vervoersopdrachten tegelijk uitvoeren en werkinstructies ontvangen van hun eigen werkgever, zoals het geval was in de hiervoor besproken uitspraak van het Hof Arnhem-Leeuwarden. Doordat onduidelijk is waar het werk wordt verricht, missen de werknemers de bescherming van de Detacheringsrichtlijn. Ook de Europese Commissie onderkent deze problematiek en kondigt in het voorstel tot aanpassing van de Detacheringsrichtlijn aan dat er sectorspecifieke wetgeving komt, samen met andere EU-initiatieven die gericht zijn op het verbeteren van de interne wegvervoermarkt. ${ }^{65}$ Minister Asscher verwacht dat de Europese Commissie nog deze zomer met een 'transportpakket' zal komen. ${ }^{66}$ Op het moment van schrijven is hierover nog niets bekend.

\subsection{Het minimumniveau aan bescherming}

Hoewel de Detacheringsrichtlijn de verschillende normen coördineert die er op nationaal niveau bestaan, heeft de Detacheringsrichtlijn in zekere zin ook invloed op de hardekern-arbeidsvoorwaarden in materiële zin. De Detacheringsrichtlijn regelt dat de hardekern-arbeidsvoorwaarden volgen uit een wet of algemeen verbindend verklaarde cao's onder wier werkingssfeer de buitenlandse ondernemer

63 Hof Den Bosch 24 mei 2016, JAR 2016/163, m.nt Laagland (Farm Trans).

64 Waarom Nederland het tijdelijke en niet het gewoonlijke werkland was, valt uit het arrest niet op te maken. De feiten uit de zaak bieden voor een nadere analyse op dit punt onvoldoende houvast. Indien niet aan tijdelijkheid maar wel aan grensoverschrijdende detachering is voldaan, hebben we te maken met permanente detachering en geldt het regime als uiteengezet in paragraaf 4 .

65 Overweging 10 preambule Voorstel tot aanpassing van de Detacheringsrichtlijn.

66 Kamerstukken II 2015/16, 34439, 4, p. 15. 
valt (artikel 3 lid 8 Detacheringsrichtlijn). ${ }^{67}$ Alleen in deze situaties kan men spreken van hardekern-arbeidsvoorwaarden waaraan de ondernemer gehouden is uitvoering te geven in relatie tot zijn tijdelijk naar het buitenland gedetacheerde werknemers. Het is deze systematiek die in de zaak Laval tot problemen leidde. In Zweden bestaat geen wettelijk minimumloon, noch een systeem tot het algemeen verbindend verklaren van cao's. ${ }^{68}$ Het Zweedse recht laat de vaststelling van een minimumloon over aan werkgevers- en werknemersorganisaties. Toen de Letse ondernemer weigerde een cao te sluiten, trachtten Zweedse vakbonden de Letse ondernemer daartoe te dwingen via een staking. Zoals bekend, achtte het Hof van Justitie de staking in strijd met de vrijheid van diensten.

Het Zweedse probleem doet zich in Nederland niet voor. Nederland kent sinds 1969 een wettelijk minimumloon. In aanvulling daarop kan de gedetacheerde buitenlandse werknemer rechten ontlenen aan cao's. Het Europese recht staat toe dat Nederland de werkingssfeer van cao's uitbreidt tot alle personen die tijdelijk in Nederland werkzaam zijn, ook al is de werkgever in een andere lidstaat gevestigd. ${ }^{69}$ In Nederland is daarvoor vereist dat de cao algemeen verbindend is verklaard en de buitenlandse ondernemer onder de werkingssfeer van de desbetreffende cao valt (artikel 2 lid 1 jo. lid 6 Wet op het algemeen verbindend en het onverbindend verklaren van bepalingen van collectieve arbeidsovereenkomsten (Wet AVV)). De Wet arbeidsvoorwaarden gedetacheerde werknemers in de Europese Unie heeft hierin geen verandering aangebracht. ${ }^{70}$ De vraag is alleen: wanneer valt een buitenlandse werkgever onder de werkingssfeer van een algemeen verbindend verklaarde cao?

De tweede zin van artikel 2 lid 1 Wet AVV luidt: 'De bepalingen zijn (...) binnen dat gebied verbindend voor alle werkgevers en werknemers, die naar den aard van den arbeid, waarop zij betrekking hebben, onder de collectieve arbeidsovereenkomst vallen (...).' De wet neemt de aard van de te verrichten arbeid als uitgangspunt. Dat doet vermoeden dat een buitenlandse ondernemer die in Nederland arbeid laat verrichten automatisch valt onder de algemeen verbindend verklaarde cao van de sector waarbinnen het werk wordt verricht. Toch is dat niet het geval. De Hoge Raad overwoog in 1995 dat artikel 2 Wet AVV slechts een aanvullende betekenis heeft ten opzichte van een expliciete werkingssfeerbepaling in de cao zelf. $^{71}$

67 Indien een stelsel ontbreekt voor het algemeen verbindend verklaren van cao's, biedt de Detacheringsrichtlijn in artikel 3 lid 8 tweede alinea alternatieve technieken. Deze technieken blijven in dit artikel buiten beschouwing.

68 Het systeem in Zweden is inmiddels aangepast. Zie over het Zweedse system in het algemeen: M. Kullmann, De handhaving van het arbeidsrecht in grensoverschrijdende situaties (diss. RU), Kluwer: Deventer 2015, en meer specifiek in relatie tot de zaak Laval: M. Rönnmar, Laval returns to Sweden: The Final Judgment of the Swedish Labour Court and Swedish Legislative Reforms, Industrial Law Journal 2010, 3, p. 280-287.

69 Zie overweging 20 preambule Detacheringsrichtlijn; HvJ EG 23 november 1999, C-369/96 en C-376/96 (Arblade), punt 41.

70 Deze wet implementeert de Handhavingsrichtlijn in het Nederlandse recht en is op 18 juni 2016 in werking getreden. Met deze wet is de Waga vervangen en onder meer artikel 2 lid 6 Wet AVV aangepast.

71 HR 6 januari 1995, NJ 1995/549; HR 27 oktober 1995, NJ 1996/257. 
Doorgaans neemt de minister de werkingssfeer over die door de vakorganisaties is vastgesteld. Op dat moment vervangt de werkingssfeerbepaling uit de cao artikel 2 Wet AVV. Sluit de cao aan bij de aard van de arbeid, dan kunnen gedetacheerde werknemers in de desbetreffende sector aan de cao rechten ontlenen. Dat is anders indien de algemeen verbindend verklaarde cao verwijst naar Nederland als vestigingsplaats van de werkgever. ${ }^{72}$ Inmiddels kennen tal van Nederlandse cao's een specifiek hoofdstuk gericht op buitenlandse ondernemers die werknemers tijdelijk naar Nederland detacheren. ${ }^{73}$

\subsection{Het maximumniveau aan bescherming}

Hoewel de Detacheringsrichtlijn in artikel 3 lid 7 lidstaten toestaat arbeidsvoorwaarden op te stellen die gunstiger voor werknemers zijn, ${ }^{74}$ komt aan deze bepaling slechts beperkte betekenis toe. Het Hof van Justitie overwoog in het hiervoor besproken arrest Laval dat het de ontvangstlidstaat niet is toegestaan de verrichting van diensten op zijn grondgebied afhankelijk te stellen van de inachtneming van arbeidsvoorwaarden die verder gaan dan de dwingende bepalingen voor minimale bescherming. ${ }^{75}$ Het argument dat wordt getracht social dumping tegen te gaan, gaat niet op omdat de Detacheringsrichtlijn reeds in de bescherming van werknemers voorziet.

Ik acht het evenmin mogelijk andere nationale aspecten dan de hardekernarbeidsvoorwaarden via de weg van artikel 9 Rome I-Verordening op de arbeidsovereenkomst van toepassing te verklaren. Het Hof van Justitie overwoog in het arrest Unamar dat nationale regels die verder gaan dan het geharmoniseerde minimum, voorrangsregels kunnen zijn. ${ }^{76}$ Echter, nu verdergaande arbeidsrechtelijke bepalingen een uitzondering vormen op de hardekern-arbeidsvoorwaarden, moet artikel 9 Rome I-Verordening bij tijdelijke detachering zeer strikt worden opgevat. Dat was ook de benadering van het Hof van Justitie in het arrest Commissie/Luxemburg. ${ }^{77}$ Hoewel het in dit arrest ging om artikel 3 lid 10 Detache-

72 Dit is bijvoorbeeld het geval in de cao Beroepsgoederenvervoer. Voor buitenlandse uitzendbureaus is een uitzondering geformuleerd in artikel 9, maar voor contracting ontbreekt een gelijkluidende bepaling. Zie hierover mijn noot in JAR 2016/163. De beperking in de werkingssfeer geldt ook indien artikel 8 Rome I-Verordening Nederlands recht aanwijst als het objectief toepasselijke recht. Onjuist is dan ook de uitspraak van het Hof Den Bosch 28 mei 2013, JAR 2013/159 (Mooy), m.nt. Franssen.

73 Zie bijvoorbeeld de cao Bouwnijverheid 2015-2017, artikel 7.

74 Het lijkt in artikel 3 lid 7 te gaan om gunstigere arbeidsvoorwaarden ten aanzien van de aangelegenheden als geregeld in artikel 3 lid 1 (de hardekern-arbeidsvoorwaarden). Artikel 3 lid 10 heeft immers betrekking op andere aangelegenheden en kent in dat verband een zeer stringente toets.

75 HvJ EG 18 december 2007, JAR 2008/21 (Laval), punt 80.

76 HvJ EG 17 oktober 2013, C-184/12 (Unamar), m.nt. Van Overbeeke in SEW 2014/9. Het gaat wel om een zware toets. Vereist is dat de rechter omstandig vaststelt dat de wetgever van de lidstaat waar de zaak wordt behandeld het in het kader van de omzetting van de richtlijn van fundamenteel belang heeft geacht een bescherming te bieden die ruimer is dan die waarin de richtlijn voorziet.

77 HvJ EU 19 juni 2008, C-319/06 (Commissie/Luxemburg). 
ringsrichtlijn, ligt het voor de hand dat artikel 9 Rome I-Verordening in het licht van de Detacheringsrichtlijn gelijkluidend wordt uitgelegd. ${ }^{78}$

Los hiervan kan men zich afvragen of arbeidsrechtelijke bepalingen die vallen onder het bereik van artikel 8 Rome I-Verordening tevens de status van voorrangsregel kunnen hebben. Ter illustratie het volgende. Bij de tijdelijke detachering van een Pool naar Nederland verwijst artikel 8 Rome I-Verordening naar Pools recht, zodat de dwingende bepalingen van het Poolse (en niet het Nederlandse) recht op de arbeidsovereenkomst van toepassing zijn. Het zou gek zijn als Nederland dwingende bepalingen die vallen binnen het bereik van artikel 8 Rome I-Verordening de status van voorrangsregel kan geven, zodat de Nederlandse (en niet de Poolse) bepalingen via artikel 9 Rome I-Verordening alsnog op de arbeidsovereenkomst van toepassing zijn. Daarmee wordt de betekenis van artikel 8 Rome I-Verordening ondermijnd. Deze uitleg ligt, gezien het beschermende karakter van artikel 8 Rome I-Verordening, niet voor de hand.

Er bestaat een aantal uitzonderingen op het verbod tot het toekennen van een hoger beschermingsniveau. De rechtspraak leert dat een hoger beschermingsniveau is toegestaan als de werkgever vrijwillig toetreedt tot een cao in het tijdelijke werkland of als het hogere niveau blijkt uit het herkomstland. ${ }^{79}$ Het is onduidelijk wat het Hof van Justitie bij de tweede uitzondering bedoelt met het herkomstland. Ik verwacht dat de uitzondering is gestoeld op het gunstigheidsprincipe en het Hof van Justitie het oog had op het objectief toepasselijke recht dat op de arbeidsovereenkomst van toepassing is. Met andere woorden: als een Nederlander tijdelijk naar Polen wordt gedetacheerd, behoudt hij recht op de Nederlandse hardekern-arbeidsvoorwaarden omdat deze voor hem gunstiger zijn dan het Poolse equivalent. Het voorstel tot aanpassing van de Detacheringsrichtlijn ondersteunt deze zienswijze. ${ }^{80}$

Een andere uitzondering bestaat voor uitzendrelaties. Een gelijkstelling tussen uitzendkrachten en reguliere werknemers in dienst van de inlener geldt in een nationale context op basis van de Uitzendrichtlijn. Dit volgt in Nederland uit artikel 8 van de Wet allocatie arbeidskrachten door intermediairs (Waadi). ${ }^{81}$ Artikel 3 lid 9 Detacheringsrichtlijn biedt lidstaten de mogelijkheid de gelijkstelling door te trekken naar buitenlandse uitzendkrachten. Nederland heeft dit artikel niet geïmplementeerd. ${ }^{82}$ In het voorstel tot aanpassing van de Detacheringsrichtlijn stelt

Op artikel 3 lid 10 Detacheringsrichtlijn kan slechts een beroep worden gedaan bij een werkelijke en voldoende ernstige bedreiging van een fundamenteel belang van de samenleving (zie punt 50). Dit begrip lijkt een striktere invulling te vereisen dan het begrip voorrangsregels in het arrest Unamar (zie noot hiervoor). Men zou ook kunnen betogen dat aan artikel 9 Rome I-Verordening geen betekenis toekomt, omdat de Detacheringsrichtlijn met artikel 3 lid 10 expliciet aangeeft wanneer uitbreiding tot andere aangelegenheden dan de hardekern-arbeidsvoorwaarden is toegestaan.

79 Zie HvJ EG 3 april 2008, C-346/06 (Rüffert), punt 34.

80 Voorstel tot aanpassing van de Detacheringsrichtlijn.

81 Van artikel 8 Waadi kan bij cao worden afgeweken. De ABU-cao (die doorgaans algemeen verbindend is verklaard) bepaalt evenwel dat uitzendkrachten vanaf de eerste werkdag recht hebben op de inlenersbeloning (artikel 19 ABU-cao).

Dat heeft hoogstwaarschijnlijk te maken met de concurrentiepositie. 
de Europese Commissie de gelijkstelling in een grensoverschrijdende context verplicht. Het is vooral deze bepaling die ertoe zal hebben geleid dat Oost-Europese lidstaten een gele kaart hebben getrokken. Dat verbaast niet. Bij een gelijkstelling moeten buitenlandse uitzendbureaus aan hun naar het buitenland gedetacheerde werknemers vanaf de eerste werkdag de hardekern-arbeidsvoorwaarden, zoals het (cao-)loon, betalen dat nationale uitzendkrachten en daarmee gelijk te stellen werknemers in dienst van de inlener ontvangen. Daaraan zullen buitenlandse uitzendbureaus doorgaans niet kunnen voldoen.

Op basis van het huidige recht zijn buitenlandse uitzendbureaus alleen verplicht tot betaling van het inlenersloon in de periode dat de Uitzend-cao algemeen verbindend is verklaard. Artikel 8 Waadi kan niet als voorrangsregel in de zin van artikel 9 Rome I-Verordening worden beschouwd, zodat de gelijkstelling niet geldt voor avv-loze periodes. Hoewel artikel 3 lid 9 Detacheringsrichtlijn toestaat dat een lidstaat het beschermingsniveau van nationale en buitenlandse uitzendkrachten aan elkaar gelijkstelt, vereist deze bepaling implementatie via wetgeving en daartoe is Nederland zoals gezegd niet overgegaan. De verplichting kunnen rechters in mijn visie niet via artikel 9 Rome I-Verordening aan buitenlandse uitzendbureaus opleggen. Dit neemt niet weg dat Nederland alsnog artikel 3 lid 9 Detacheringsrichtlijn kan implementeren, eventueel in samenspraak met de andere ondertekenaars van de brief aan Eurocommissaris Thyssen (allemaal landen met een hoog loonniveau). ${ }^{83}$ In feite wordt dan hetzelfde effect bereikt als wat het voorstel tot aanpassing van de Detacheringsrichtlijn beoogt. De gelijkschakeling heeft immers vooral effect in de situatie dat uitzendbureaus uit landen met een laag loonniveau hun uitzendkrachten naar landen met een hoog loonniveau detacheren, en niet andersom.

\subsection{Uitzending versus intra-concernuitlening}

De ABU-cao kent een speciale afdeling voor buitenlandse uitzendbureaus die werknemers tijdelijk naar Nederland uitzenden (artikel 68). Op basis van dit artikel hebben de vanuit het buitenland tijdelijk naar Nederland gedetacheerde uitzendkrachten tijdens algemeen verbindend verklaarde periodes recht op de hardekern-arbeidsvoorwaarden uit de cao, waaronder de inlenersbeloning vanaf de eerste werkdag (artikel 19).

In Nederland bestaat discussie over de vraag of een personeels-bv die werknemers aan groepsonderdelen ter beschikking stelt, kan vallen onder het bereik van artikel 7:690 BW en dus de ABU-cao. ${ }^{84}$ Deze discussie spitst zich toe op de nationale context, maar is ook relevant voor grensoverschrijdende intra-concernuitlening. Op het moment zijn twee zaken bij de Hoge Raad aanhangig waarin het toepassingsbereik van artikel 7:690 BW centraal staat. A-G Van Peursem stelt in zijn conclusie inzake STIPP/C4C dat artikel 7:690 BW een ruime of helemaal geen allocatiefunctie nodig heeft. ${ }^{85}$ Even verderop lijkt A-G Van Peursem toch wel 
enige allocatiefunctie te vereisen. ${ }^{86}$ De laatste overweging sluit aan bij de opvatting van A-G Wattel in zijn conclusie inzake de premiesectorindeling werknemersverzekering. ${ }^{87}$ Beide A-G's lijken aldus van mening dat artikel 7:690 BW enige functie vereist op het terrein van het bij elkaar brengen van vraag en aanbod, maar niet is beperkt tot de klassieke allocatiefunctie. ${ }^{88}$ Met andere woorden: vervult de personeels-bv enige allocatiefunctie, dan valt het bedrijf onder de werkingssfeer van de algemeen verbindend verklaarde ABU-cao. Deze redenering kan men doortrekken naar de buitenlandse personeels-bv. ${ }^{89}$ Aan een allocatiefunctie is mijns inziens voldaan indien het de personeels-bv is die de werknemers werft en selecteert. ${ }^{90}$

Doorgaans zal de buitenlandse personeels-bv de werknemers uit dat land zelf werven en selecteren. Maar wat als dat niet het geval is en de personeels-bv aldus geen enkele allocatiefunctie op de arbeidsmarkt vervult? In dat geval mist de Detacheringsrichtlijn in mijn ogen toepassing. De Handhavingsrichtlijn vereist in artikel 3 dat de buitenlandse ondernemer ondernemingsactiviteiten verricht en daaraan is niet voldaan indien de personeels-bv slechts de personeelsadministratie voor haar rekening neemt. De Handhavingsrichtlijn bepaalt echter niet wat geldt nu de Detacheringsrichtlijn buiten toepassing blijft. Bestaat er wel een dienstverband met de buitenlandse personeels-bv? Ik verwacht van wel. Het feit dat de buitenlandse ondernemer geen substantiële ondernemingsactiviteiten verricht, betekent niet dat hij niet in het buitenland is gevestigd. Met andere woorden: de buitenlandse rechtspersoon blijft bestaan en met deze rechtspersoon zijn de werknemers een arbeidsovereenkomst aangegaan. Op basis van artikel 8 Rome I-Verordening zal Nederland doorgaans het gewoonlijke werkland zijn, ${ }^{91}$ maar de voordelen van algemeen verbindend verklaarde cao's geniet de buitenlandse werknemer niet. De ABU-cao is niet van toepassing op personeels-bv's zonder allocatiefunctie, en de personeels-bv valt evenmin onder enig andere algemeen

86 Conclusie A-G Van Peursem 15 april 2016, ECLI:NL:PHR:2016:238 (C4C/STIPP), r.o. 3.30.

87 Conclusie A-G Wattel 14 april 2016, ECLI:NL:PHR:2016:239.

88 Deze opvatting is ruimer dan de Uitzendrichtlijn, die uitgaat van de klassieke allocatiefunctie (het bij elkaar brengen van vraag en aanbod op tijdelijke basis). De Uitzendrichtlijn verbiedt echter niet dat aan artikel 7:690 BW een breder toepassingsbereik wordt toegekend.

89 Ook in groepsverband is sprake van een derde. Zou het anders zijn, dan is onduidelijk waarom concernuitlening is uitgezonderd van het artikel 7:691 BW-regime (zie lid 6). Vergelijk HR 17 juni 2011, USZ 2011/218; Ktr. Arnhem 17 mei 2015, JAR 2015/303 (SNCU/Logiflex); E. Knipschild in haar noot in JAR 2015/69.

90 De Detacheringsrichtlijn maakt een onderscheid tussen uitzending (type c) en intra-concernuitlening (type b). Dit betekent mijns inziens niet dat intra-concernuitlening geen uitzending kan zijn.

91 Nu de Detacheringsrichtlijn niet geldt, wordt de grensoverschrijdende detachering beoordeeld in het licht van artikel 8 Rome I-Verordening (en niet de Detacheringsrichtlijn). Dit geldt ook voor de beoordeling van tijdelijkheid, zodat van tijdelijkheid slechts sprake is indien de detachering binnen een bestaand dienstverband plaatsvindt. Daaraan is bij een exclusieve tewerkstelling binnen het concernverband niet voldaan: Nederland is daarom vanaf de eerste werkdag het gewoonlijke werkland. Zie ter vergelijking paragraaf 3.3. 
verbindend verklaarde Nederlandse cao. Ook de Waadi - in het bijzonder artikel 8 - is niet van toepassing. ${ }^{92}$

De Nederlandse inlener waaraan de buitenlandse werknemer ter beschikking is gesteld, valt doorgaans wel onder de werkingssfeer van enige cao. Het is daarom lucratief voor de buitenlandse werknemer om (ook) een arbeidsovereenkomst te kunnen claimen met het Nederlandse concernonderdeel waaraan hij ter beschikking is gesteld. ${ }^{93}$ Ik geef de buitenlandse werknemer daartoe goede kansen. Het Hof van Justitie acht het mogelijk dat een ander dan de formele werkgever (met wie is gecontracteerd) als de werkgever wordt beschouwd bij toepassing van de Rome I-Verordening. ${ }^{94}$ Bovendien leert het Albron-arrest dat het Hof van Justitie er niet voor terugdeinst de economische realiteit te laten prevaleren. ${ }^{95} \mathrm{Bij}$ een direct dienstverband met de inlener kan de werknemer via de artikelen 8 en 9 Rome I-Verordening rechten ontlenen aan de algemeen verbindend verklaarde cao onder wiens toepassingsbereik de inlener valt. Als de inlener door lidmaatschap is gebonden aan een cao, heeft de werknemer dit recht op grond van artikel 8 Rome I-Verordening zelfs in avv-loze periodes.

\subsection{Uitzending versus contracting}

Anders dat bij uitzending en intra-concernuitlening geldt bij contracting dat de buitenlandse werknemers het werk in Nederland verrichten onder het toezicht en gezag van de eigen werkgever. Dat kan op basis van een overeenkomst van opdracht of op basis van onderaanneming. Voor buitenlandse uitzendbureaus biedt contracting een aantrekkelijk alternatief voor uitzending. De ABU-cao is niet van toepassing (contracting valt niet onder artikel 7:690 BW) en als de buitenlandse werkgever zich bezighoudt met verschillende activiteiten, valt hij bovendien buiten het bereik van enig andere algemeen verbindend verklaarde cao. Uit de schaarse rechtspraak blijkt dat kantonrechters bij onduidelijkheid vrij snel tot de conclusie komen dat sprake is van een uitzendrelatie. ${ }^{96}$ Bij de uitspraken kunnen vraagtekens worden geplaatst; de motivering is niet steeds even helder. Ik sluit niet uit dat de onduidelijke feiten en de gedachte dat misbruik moet

92 Hoewel artikel 8 Waadi een bepaling is van dwingend recht (en dus valt binnen het bereik van artikel 8 Rome I-Verordening), is het ter beschikking stellen van werknemers binnen concernverband van de Waadi uitgesloten op grond van artikel 1 lid 3 (c) Waadi.

93 In een Nederlandse nationale context hanteren rechters bij het gebruik van personeels-bv's (niet zijnde uitzendbureaus) de techniek vereenzelviging, bijvoorbeeld in de situatie dat de werknemer tewerkstelling vordert bij de inlener. Zie bijvoorbeeld Hof Amsterdam 10 juni 2014, ECLI: NL:GHAMS:2014:2223 en Hof Amsterdam 14 februari 2012, ECLI:NL:GHAMS:2012:BV8922. De techniek vereenzelviging kent in een grensoverschrijdende context het probleem dat niet duidelijk is in welk land moet worden aangenomen dat de vereenzelvigde vennootschappen zich bevinden. Is dat het land waar de personeels-bv is gevestigd of het land waar de inlener is gevestigd?

94 HvJ EU 15 december 2011, C-384/10 (Voogsgeerd/Navimer SA).

95 HvJ EU 21 oktober 2010, C-242/09, JAR 2010/298 (Albron/Roest).

96 Zie Ktr. Assen 4 maart 2015, JAR 2015/85 (FNV/Waterhuizen). Zie voor een nationale zaak Hof Den Bosch 21 oktober 2014, JAR 2015/10, m.nt. Zwemmer (SNCU/Qatro). 
worden voorkomen een rol hebben gespeeld bij het oordeel dat sprake was van uitzending in plaats van contracting. ${ }^{97}$

Ook vakorganisaties denken na over wijzen waarop de voordelen van grensoverschrijdende contracting kunnen worden voorkomen. Interessant is artikel 73 van de cao Beroepsgoederenvervoer. Artikel 73 bepaalt kort gezegd dat de Nederlandse opdrachtgever gehouden is in overeenkomsten van onderaanneming, die in of vanuit Nederland gevestigde ondernemingen van de opdrachtgever worden uitgevoerd, te bedingen dat de onderaannemer aan zijn werknemers de basisarbeidsvoorwaarden van de cao zal toekennen wanneer dat voortvloeit uit de Detacheringsrichtlijn. De cao-bepaling richt zich aldus tot de Nederlandse opdrachtgever die onder het toepassingsbereik van de cao Beroepsgoederenvervoer valt. Het is het Nederlandse transportbedrijf dat van de buitenlandse onderaannemer moet eisen dat de harde kern van arbeidsvoorwaarden uit de cao Beroepsgoederenvervoer worden nageleefd. Maar kan de Nederlandse ondernemer daartoe wel worden verplicht? Dat betwijfel ik.

Zoals hiervoor in paragraaf 5.2 bleek, is het Nederland als tijdelijk werkland niet toegestaan de verrichting van diensten op zijn grondgebied afhankelijk te stellen van de inachtneming van arbeidsvoorwaarden die verder gaan dan de dwingende bepalingen voor minimale bescherming uit de Detacheringsrichtlijn. Met andere woorden: alleen wanneer de buitenlandse ondernemer valt onder de werkingssfeer van de algemeen verbindend verklaarde cao Beroepsgoederenvervoer, kan van hem worden geëist de harde kern van arbeidsvoorwaarden uit de cao toe te passen. En daar gaat het naar mijn mening fout. De werkingssfeerbepaling in de cao Beroepsgoederenvervoer sluit in artikel 1 aan bij Nederland als vestigingsplaats van de werkgever. De in het buitenland gevestigde werkgever valt daarbuiten. Voor buitenlandse uitzendbureaus maakt artikel 9 hierop een uitzondering, maar een soortgelijke bepaling lees ik voor onderaanneming niet terug.

Het buitenlandse transportbedrijf is daarom niet gehouden de harde kern van arbeidsvoorwaarden uit de cao Beroepsgoederenvervoer op de arbeidsovereenkomst van zijn Poolse werknemers toe te passen en kan en mag daartoe ook niet worden verplicht in het licht van de vrijheid van diensten. Het arrest Laval maakt duidelijk dat de vrijheid van diensten naast verticale ook horizontale werking heeft. De vrijheid van diensten staat er aldus aan in de weg dat het Nederlandse transportbedrijf in deze specifieke situatie het buitenlandse transportbedrijf verplicht de hardekern-arbeidsvoorwaarden na te leven.

Het voorstel tot aanpassing van de Detacheringsrichtlijn doet een poging misbruik van grensoverschrijdende contracting aan banden te leggen. ${ }^{98}$ De Europese Commissie wil lidstaten de mogelijkheid geven nationale ondernemers te verplichten enkel buitenlandse partijen te contracteren die aan hun werknemers de bezoldigingsvoorwaarden toekennen die voor de nationale ondernemer gelden, met inbegrip van voorwaarden die het resultaat zijn van niet algemeen verbin-

97 Vergelijk J.P.H. Zwemmer, Contracting en arbeidsrecht: over schijnconstructies, juridisch houdbare varianten en de gevolgen van de WAS en de WWZ, TAP 2015/118.

98 Voorstel tot aanpassing van de Detacheringsrichtlijn, p. 8-9. Wel is vereist dat de verplichting ook geldt voor binnenlandse ondernemers. 
dende collectieve overeenkomsten. Deze bepaling gaat een stuk verder dan wat de Detacheringsrichtlijn nu bepaalt. Mocht het voorstel worden aangenomen, dan lijkt voldoende dat de Nederlandse ondernemer die het werk uitbesteedt aan de cao is gebonden, ofwel via lidmaatschap, ofwel via algemeenverbindendverklaring. Of de buitenlandse werkgever onder de werkingssfeer van de cao valt, is niet langer relevant. Uiteraard moet Nederland dan wel de keuzemogelijkheid die het voorstel biedt, implementeren.

\section{Gebrek aan een eenduidig arbeidsrechtelijk regime}

Het Unieverdrag schrijft voor dat de Europese Unie zich moet inzetten voor een sociale-markteconomie met een groot concurrentievermogen, gericht op werkgelegenheid en sociale vooruitgang. Waar de nadruk van het Europese integratieproces in de beginjaren veelal lag op de economische doelstellingen, lijkt er steeds meer aandacht voor de sociale aspecten. Met betrekking tot grensoverschrijdende detachering blijkt het vinden van de juiste balans echter niet eenvoudig. Daar komt bij dat de verschillende regels (op Europees en nationaal niveau) niet steeds goed op elkaar zijn afgestemd. Hierdoor is een wirwar van regelgeving ontstaan waar dienstverleners handig gebruik van kunnen maken. Het voorstel tot aanpassing van de Detacheringsrichtlijn maakt het speelveld er niet eenvoudiger op. Het voorstel heeft betrekking op het voorkomen van misbruik, maar doet dat vooral door - naar het lijkt - tijdelijke detachering minder aantrekkelijk te maken. De afwijkende regimes blijven in stand, sterker nog: de verschillen worden vergroot. Zo is het principe van gelijk loon voor gelijke arbeid bijvoorbeeld niet op intraconcernuitlening van toepassing verklaard. Wellicht omdat intra-concernuitlening (ook) kan vallen onder uitzending, maar zeker is dat niet.

Het zou een stap voorwaarts zijn indien de regels minder complex en meer eenduidig zouden zijn. Maar kan dat wel? Uiteraard. Er valt iets voor te zeggen uitzending en intra-concernuitlening uit de Detacheringsrichtlijn te halen en te plaatsen in het licht van de vrijheid van werknemers en de systematiek van artikel 8 Rome I-Verordening. In beide gevallen treden de werknemers toe tot de arbeidsmarkt van het ontvangstland en is het niet vreemd dat deze groep ook als zodanig wordt behandeld. Beide vormen onderscheiden zich in die zin van contracting, waarbij het gaat om zuivere dienstverlening en de vrijheid van diensten logischerwijs het speelveld bepaalt. Een aanpassing zoals deze vereist echter politieke wil en de reactie van de elf lidstaten op het voorstel tot aanpassing van de Detacheringsrichtlijn spreekt boekdelen. Het ziet ernaar uit dat het labyrint van regelgeving nog wel even zal bestaan. 